\title{
循環器病棟における薬学的支援の取り組み
}

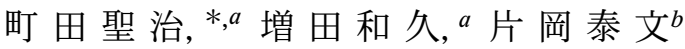

\section{Pharmaceutical Support at Cardiovascular and Cardiovascular Surgery Ward}

\author{
Seiji MACHIDA, ${ }^{*, a}$ Kazuhisa MASUdA, ${ }^{a}$ and Yasufumi KATAOKA ${ }^{b}$ \\ ${ }^{a}$ Dept. Pharm. Kokura Memorial Hospital, 1-1 Kifunemachi, Kokurakita-ku, Kitakyushu 802-8555, \\ Japan, and ${ }^{b}$ Fac. Pharm. Sci., Fukuoka University, 8-19-1 Nanakuma, \\ Johnan-ku, Fukuoka 814-0180, Japan
}

(Received July 2, 2007)

\begin{abstract}
Pharmacological support for the appropriate use of drugs is important. To promote such support, it is necessary to be involved in drug therapy from viewpoints different from those of physicians and nurses, using tools unique to pharmacists, pharmacologically discuss individual cases, and investigate the validity of prescriptions by accumulating data. In Chapter 1, digoxin is necessary to monitor therapy very closely. In addition, patients with an impaired renal dysfunction have a predisposition for developing digitalis toxicity. In clinical cases, digoxin and verapamil are often co-administered for heart rate control, and we have observed the serum trough level of beta-methyldigoxin to be elevated due to drug-interaction. We build upon our previous findings and generated a simple index for the adequate administration dosage of beta-methyldigoxin based on variable degrees of renal function and the serum trough level of beta-methyldigoxin. In Chapter 2, to investigate risk factors of postoperative infection following cardiac surgery, we conducted a retrospective analysis of two surgical procedures, off-pump coronary artery bypass grafting (OPCAB) and surgery for valvular heart disease (valve operation). After discussing the analysis results with the respective physicians, the dosing guidelines for cefazolin (CEZ) were changed. We also analyzed the rate of CEZ replacement with other antibiotics after surgery finding that it decreased in both groups for OPCAB and valve operations. From these results, we conclude that, if CEZ is also administered intra-operatively when surgery is prolonged, its administration for two days following surgery is adequate for prophylaxis against postoperative infection.
\end{abstract}

Key words_— pharmacological support; beta-methyldigoxin; renal function; postoperative infection; cardiac surgery; cefazolin

\section{1. はじめに}

病院薬剂師の業務は多岐に渡り, 薬剤管理指導業 務を始め, 薬物血中濃度モニタリング（血中濃度解 析による薬学的な根拠に基づいた処方支援)，薬剤 モニタリングによる副作用症状の重篤化回避（プレ アボイド報告)，抗がん剤を始めとした注射薬調剤 等が挙げられる.

中でも「薬凨管理指導業務」は, 薬剂の有効性や 安全性の確保に係わる主要な業務として位置付けら れ，本業務を通じた薬剤の適正使用に向けた薬学的

$a$ 社会保険小倉記念病院薬剂部（８002-8555 北九州市 小倉北区貴船町 1-1)

$b$ 福岡大学薬学部薬学疾患管理学教室（T814-0180 福 岡市城南区七隈 8-19-1)

*e-mail: machida-s@kokurakinen.or.jp

本総説は, 日本薬学会第 127 年会シンポジウム S47 で 発表したものを中心に記述したものである.
支援に取り組むことも重要となる，それを推進する ためには，薬剤管理指導業務で判明した問題点を薬 剂師独自のツールにより医師や看護師とは違った観 点から薬学的考察を加えると同時に, デー夕蓄積に よる処方の妥当性を検討していく必要がある。一 方，その結果が患者へどのような形で還元され得る か熟慮していく必要性もあり，そのためにもべッド サイドでの薬剤管理指導業務の実践を基本として, 薬剤の適正使用を推進していかなければならない.

薬剤適正使用の取り組みは, 薬剤管理指導業務で 経験した症例や，また治療・手術で使用されている 共通の薬剤に焦点を合わせ，ある事例（イベント） に対する原因究明や薬剤の使用に際して問題となつ ている点を解決していくことを主眼として取り組む 場合が多い。しかしながら，1 1 つ臨床事項は種々 の原因・要因が折り重なり，取り組んでいくことが 
困難である場合がある，そこで，患者の状態をより 把握し，臨床デー夕等鑑み，ある共通点を注意深く 観察していくことが, 問題解決していく方途となり 得る。今回，蓄積された臨床データにより，医薬品 適正使用の薬学的支援に関する実地的指針の策定 (その 1 : メチルジゴキシンの適正投与指針，その 2 : 術後感染予防抗菌薬セファゾリンの適正使用) を行い，薬学的管理の質的向上に寄与できたので報 告する.

\section{2. その 1：メチルジゴキシンの適正投与指針}

\section{2-1. 緒言 現在多くの施設で薬剂管理指導業} 務が実施され，患者に対する服薬指導と同時に薬物 モニタリングの実施により，有効かつ安全な薬物療 法を支援している。薬剤師には医薬品の適正使用を 推進し薬剂の効果を最大限に引き出し，副作用の発 現を回避する責務がある。

そのツールとして副作用モニタリングの標準的業 務指針の構築や薬物血中濃度モニタリング（TDM Therapeutic Drug Monitoring）の実施が重要とな る. 治療効果を最大限に高め, 副作用発現のリスク を最小限に減少させるために，薬物治療の問題点に ついて医師と協議を行い，医師の処方に対して薬学 的な根拠に基づいた処方支援を行う上で TDM 活用 能力は必須である.

今回，TDM を用いた支援の必要があるジゴキシ ンについて，薬剤管理指導業務で得られた患者情報 や臨床デー夕を基に考察を行い，その結果を臨床現 場へフィードバックする目的でメチルジゴキシンの 適正投与指針を作成した。

2-2. はじめに ジゴキシンはうつ血性心不 全・心房細動の治療薬として繁用されているが，治 療域が非常に狭く，高齢者や腎機能の低下した患者 ではジギタリス中毒を起こす可能性が高くなる．社 会保険小倉記念病院（以下，当院と略す）ではジゴ キシン錠と比較すると吸収率が高く，個体間のばら つきも比較的小さいメチルジゴキシン錠を投与する 症例が多い.

メチルジゴキシンは吸収されたのち，一部は生体 内で代謝されジゴキシンとなり，メチルジゴキシン とジゴキシンの両者が存在 ${ }^{1)} し ， そ の$ 体内動態は腎 障害時に変動する. ${ }^{2)}$ そのため，腎障害時の投与量 設計についてはジゴキシンと同様の注意が必要であ る.
ジゴキシンに関しては血中ジゴキシン濃度と腎機 能に応じた投与量設定についての報告3) はあるが, メチルジゴキシン錠に関しての報告はない。また， 臨床現場では心房細動・ 心拍数上昇の治療法として ジゴキシン製剤とベラパミル錠の併用も行われ, ${ }^{4} \mathrm{P}$ 糖蛋白を介した薬物相互作用による血中ジゴキシン 濃度の上昇には注意を要する。

したがって，ベラパミル錠併用時及び非併用時に おける患者の腎機能に応じたメチルジゴキシン錠の 投与量設定指針の作成が必要であると考え，検討を 行った.

2-3. 対象 1998 年 4 月から 2002 年 4 月まで の期間に, 当院循環器科・ 心臓血管外科でメチルジ ゴキシン錠を 1 日 1 回朝食後に投与された入院患者 を対象とし，ベラパミル錠非併用群及びベラパミル 錠併用群に分けて検討を行った。なお，ベラパミル 錠併用群について，投与量の相違による血中ジゴキ シン濃度の上昇の違いも考えられる5)が，ベラパミ ル錠併用の症例数が多くないためべラパミル錠が併 用されている全症例を一括して対象とした。なお， 透析を受けている患者は除外した。また，ジゴキシ ンと薬物相互作用を起こす可能性のある薬剤は多数 あり，すべてを考慮することは不可能である，ただ し，今回の対象症例中においてキニジン，プロパフ エノン及びクラリスロマイシン等のジゴキシンのク リアランスに大きな影響を与える薬剤は併用されて いなかったが，アミオダロン錠が併用されている症 例は存在していたため，アミオダロン錠併用患者は 除外した。

各群の対象患者の患者背景を Table 1 に示す．両 群での年齢・腎機能の間に有意な差はみられなかつ た.

2-4. 方法 メチルジゴキシン錠が投与されて 1 週間以上経過していること, 及び血中ジゴキシン 濃度の測定までに有意な腎機能の変動がないことを 確認した．採血は服用前に行われ，トラフ濃度の測 定と同時に血清クレアチニン（S-Cr）及び体重を 測定した.

血中ジゴキシン濃度はホモジニアスエンザイムイ ムノアッセイ (日立社)により測定を行った。なお， この抗体（試薬）はメチルジゴキシンとの交差反応

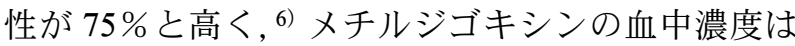
ジゴキシン濃度として表した。 
Table 1. Patient Background in the Non-verapamil Tablet-combined and Verapamil Tablet-combined Groups

\begin{tabular}{lccc}
\hline \hline & ベラパミル錠非併用群 & ベラパミル錠併用群 \\
\hline 症例数 $($ 例 $)$ & 134 (男性 $: 77$ 女性 $: 57)$ & 32 (男性 : 10 女性 : 22) \\
年齢 $($ 歳) & $66.9 \pm 9.7 \quad(37-87)$ & $68.4 \pm 9.1$ & $(46-81)$ \\
体重 $(\mathrm{kg})$ & $55.2 \pm 10.0(32.8-80.0)$ & $52.1 \pm 12.4(32.7-77.0)$ \\
$\mathrm{C}-\mathrm{Cr}(\mathrm{ml} / \mathrm{min})$ & $65.3 \pm 25.3(16.7-153.7)$ & $71.7 \pm 25.4(24.4-129.9)$ \\
メチルジゴキシン投与量 $(\mu \mathrm{g} / \mathrm{kg} / \mathrm{day})$ & $1.32 \pm 0.47(0.53-3.12)$ & $1.58 \pm 0.57(0.71-3.49)$ \\
ベラパミル投与量 $(\mathrm{mg} / \mathrm{kg} / \mathrm{day})$ & - & $2.62 \pm 0.64 \quad(80-240)$ \\
血中ジゴキシン濃度 $(\mathrm{ng} / \mathrm{ml})$ & $0.74 \pm 0.29(0.22-1.75)$ & $1.19 \pm 0.40(0.54-2.02)$ \\
\hline
\end{tabular}

Parameters other than the number of patients are expressed as the mean \pm standard deviation. The values in parentheses represent the ranges.

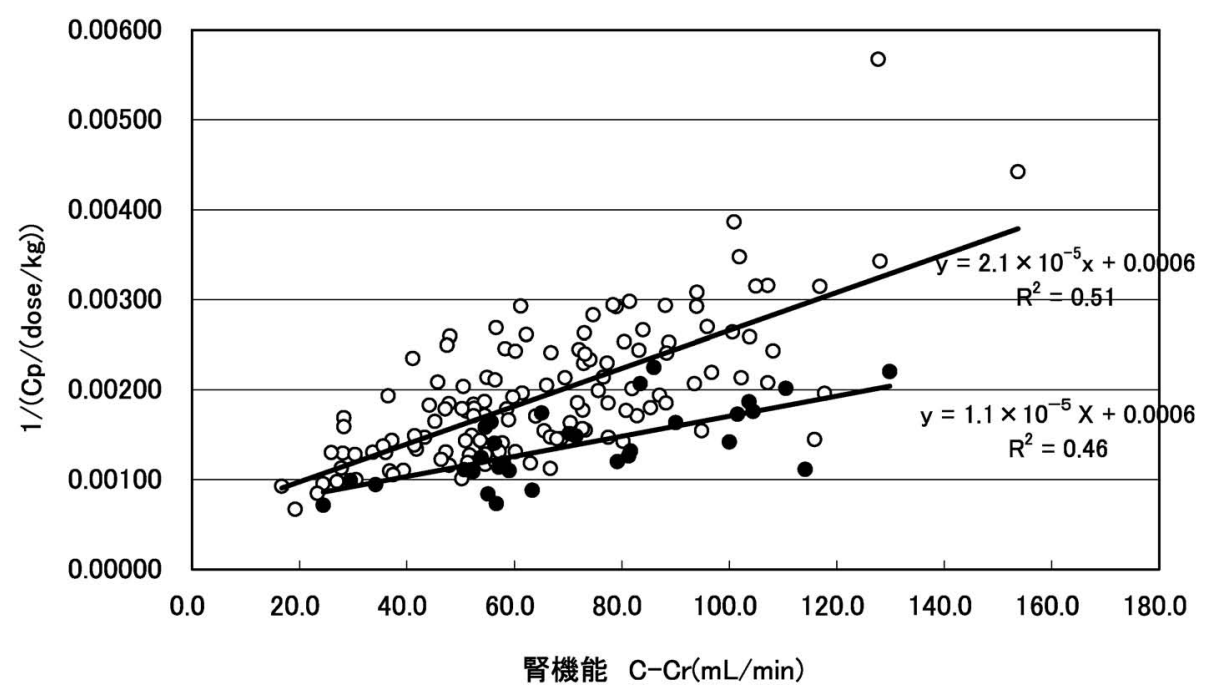

Fig. 1. Relationship between Oral Beta-methyldigoxin Clearance and Creatinine Clearance $(\mathrm{C}-\mathrm{Cr})$. White circle: Non-verapamil tablet-combined group, Black circle: Verapamil tablet-combined group.

対象患者のクレアチニンクリアランス $(\mathrm{C}-\mathrm{Cr})$ は S-Cr により下記の Cockcroft \& Gault の式7)より 推定し，この推定された $\mathrm{C}-\mathrm{Cr}$ と投与量 $(\mathrm{dose} / \mathrm{kg}$ ) に対する血中ジゴキシン濃度の比の逆数つまり, メ チルジゴキシンの経ロクリアランスについての検討 を行った.

Cockcroft \& Gault の式

$$
\begin{aligned}
\mathrm{C}-\mathrm{Cr}(\text { 男性 })= & \{(140-\text { 年齢 }) \times \text { 体重 }(\mathrm{kg})\} / \\
& \{72 \times \mathrm{S}-\mathrm{Cr}(\mathrm{mg} / \mathrm{dl})\} \\
\mathrm{C}-\mathrm{Cr}(\text { 女性 })= & \mathrm{C}-\mathrm{Cr}(\text { 男性 }) \times 0.85
\end{aligned}
$$

\section{2-5. 結果}

2-5-1. 腎機能とメチルジゴキシンの経ロクリア ランスの関係について メチルジゴキシンの経口 クリアランスと $\mathrm{C}-\mathrm{Cr}$ の関係について，ベラパミル 非併用群及び併用群とも良好な直線性を示し，正の 相関関係が認められた（Fig. 1)。ベラパミル錠非 併用群・併用群での回帰直線式と決定係数 $\left(\mathrm{R}^{2}\right)$
は下記のとおりであった。 また，腎機能との相関に ついて回帰分析を行い, $p$ 值を求めた。

ベラパミル錠非併用群 $y=2.1 \times 10^{-5} x+0.0006$

$$
\mathrm{R}^{2}=0.51 \quad p<0.0001
$$

ベラパミル錠併用群 $\quad y=1.1 \times 10^{-5} x+0.0006$

$$
\mathrm{R}^{2}=0.46 \quad p<0.0001
$$

$$
x: \mathrm{C}-\mathrm{Cr}(\mathrm{ml} / \mathrm{min})
$$

$y \quad: 1 /$ (血中ジゴキシン濃度 $(\mathrm{ng} / \mathrm{ml}) /$ 体重当 たりの投与量 $(\mathrm{mg} / \mathrm{kg})$

腎機能だけでなく，ベラパミル錠併用によるメチ ルジゴキシンの経ロクリアランスへの影響について 重回帰分析を行った結果，次の回帰直線式が得られ た.

$y=(2.10-\mathrm{VER}) \times 10^{-5} x+0.0006$

(ベラパミル錠併用時 $\mathrm{VER}=0.96$,

非併用時 VER $=0$ ) 
2-5-2. メチルジゴキシン錠の投与量設定につい て Figure 1 で得られた回帰直線式に基づき, ベ ラパミル錠非併用群及び併用群での投与量設定につ いて検討を行った.

1） ベラパミル錠非併用時の投与量設定について 回帰直線式 $y=2.1 \times 10^{-5} x+0.0006$ を用い，腎機能 及び目標とする血中ジゴキシン濃度の值により体重 当たりのメチルジゴキシンの投与量を算出し，ベラ パミル錠非併用時の投与量設定のノモグラフを作成 した. (Fig. 2).

2）ベラパミル錠併用時の投与量設定について ベラパミル錠非併用時と同様に，回帰直線式 $y=$ $1.1 \times 10^{-5} x+0.0006$ を用い，体重当たりのメチルジ ゴキシンの投与量を算出し，ベラパミル錠併用時の 投与量設定のノモグラフを作成した。（Fig. 3)。

Figure 2, Fig. 3 により，腎機能に応じた体重当 たりのメチルジゴキシンの投与量が求められ，患者 の体重を乗ずることによりメチルジゴキシンの 1 日 投与量が算出できる.

2-6. 考察 他の報告8) と同様に, 腎機能とメ チルジゴシキンの経ロクリアランスの間で正の相関 関係が認められ，また重回帰分析によりベラパミル 錠併用によるメチルジゴシキンの経ロクリアランス への影響度が示された。血中ジゴキシン濃度の上昇 率はべラパミル錠の体重当たりの投与量により異な ってくることが報告5)されているが，今回の検討で は約 50\%の血中ジゴキシン濃度の上昇が推定され る.なお，今回のべラパミル錠併用患者でのベラパ ミル錠の体重当たりの投与量は $2.62 \mathrm{mg} / \mathrm{kg}$ となつ ている.

ジゴキシンとベラパミルの併用による血中ジゴキ シン濃度上昇の原因の 1 つとして, ベラパミルが $\mathrm{P}$ 糖蛋白を介してジゴキシンの尿細管分泌を阻害し， ジゴキシンの腎外クリアランスを減少させることが 考えられ, 9) ベラパミル併用による腎クリアラン ス，腎外クリアランスへの影響について報告10)され ている. Figure 2, Fig. 3 に示したノモグラフを用 いることで，患者の腎機能と目標とする血中ジゴキ シン濃度によりメチルジゴキシン錠の 1 日投与量が 推定でき，腎機能に応じた初期投与量設定が安全か つ簡便に行えるものと考える。

まとめとして，今回得られた医薬品使用の問題点 を集積・検討し，その結果を臨床に即した医薬品適

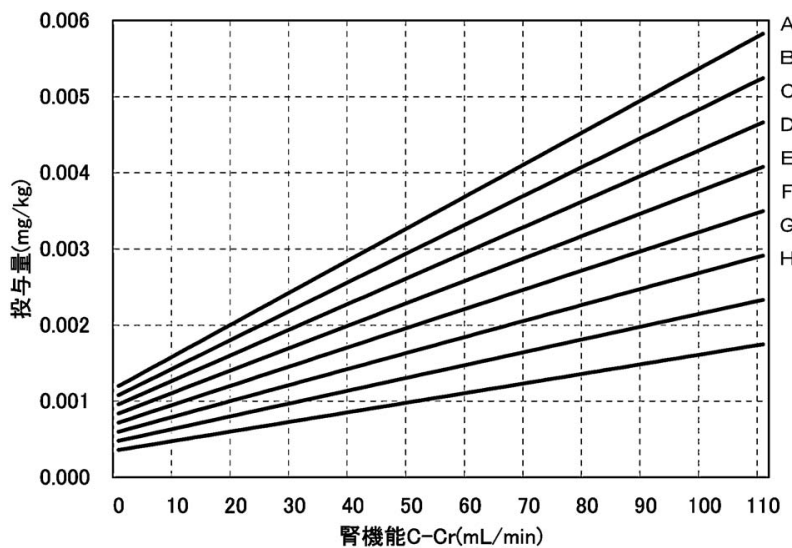

Fig. 2. Guidelines for Establishing the Initial Dose of Betamethyldigoxin Tablets (without Verapamil Tablets)

A: $2.0 \mathrm{ng} / \mathrm{ml}$, B: $1.8 \mathrm{ng} / \mathrm{ml}$, C: $1.6 \mathrm{ng} / \mathrm{ml}$, D: $1.4 \mathrm{ng} / \mathrm{ml}$, E: $1.2 \mathrm{ng} / \mathrm{ml}$, F: $1.0 \mathrm{ng} / \mathrm{ml}, \mathrm{G}: 0.8 \mathrm{ng} / \mathrm{ml}, \mathrm{H}: 0.6 \mathrm{ng} / \mathrm{ml}$

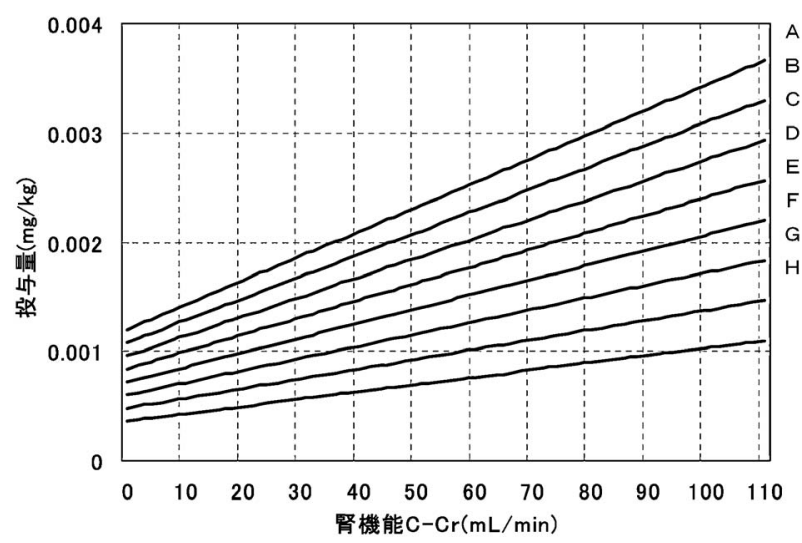

Fig. 3. Guidelines for Establishing the Initial Dose of Betamethyldigoxin Tablets (Combination Therapy with Verapamil Tablets)

A: $2.0 \mathrm{ng} / \mathrm{ml}$, B: $1.8 \mathrm{ng} / \mathrm{ml}$, C: $1.6 \mathrm{ng} / \mathrm{ml}$, D: $1.4 \mathrm{ng} / \mathrm{ml}$, E: $1.2 \mathrm{ng} / \mathrm{ml}$ F: $1.0 \mathrm{ng} / \mathrm{ml}, \mathrm{G}: 0.8 \mathrm{ng} / \mathrm{ml}, \mathrm{H}: 0.6 \mathrm{ng} / \mathrm{ml}$

正使用に応用することで，製薬会社からの医薬品情 報だけでは対応できない投与量設定指針を作成する ことができた。この指針により患者の腎機能と目標 とする血中ジゴキシン濃度によりメチルジゴキシン 錠の 1 日投与量を推定でき，投与開始時に腎機能に 応じた初期投与量設定が安全かつ簡便に行え，ジギ タリス中毒を回避できる。また臨床への応用とし て，作成した投与量設定指針を当院医薬品集付録へ 記載し，初期投与量の設定を医師と協議すると同時 に，血中ジゴキシン濃度が高值と考えられる症例に ついて血中ジゴキシン濃度測定依頼を実施している.

3. その 2 : 術後感染予防抗菌薬セファゾリンの 適正使用

3-1. 緒言 ここ数年，院内感染や耐性菌の出 
現など感染症に関する諸問題が，医療現場で解決す べき事象となっている。 そこで，大切なことは抗菌 薬の使用についての正しい知識とそれに基づく実践 である。

術後感染予防抗菌薬については, 「広い抗菌スぺ クトルを有している抗菌薬を投与することにより術 後感染症の頻度を低下させる」との観念が，従来経 験的に根強く浸透していた。この結果，メチシリン 耐性黄色ブドウ球菌（MRSA），薬剤排出機構を獲 得した多剤耐性緑膿菌，薬剤分解酵素を産生する細 菌，そして透過孔に変化を生じた細菌等，最近問題 となっている耐性菌が出現した。このような耐性菌 を出現させず術後感染症を予防するには，抗菌薬の 種類や投与量，投与方法について熟慮することが重 要である，例えば，抗菌薬を投与するタイミングや 投与期間を適切に行うことにより抗菌薬の効果を最 大限にし，耐性菌の出現や副作用を最小限にするこ とができる．術後感染症予防については外科手術に おける抗菌薬予防投与の必要性 ${ }^{11)}$ や, 術後感染症に 対する術前からの予防的抗菌薬投与の有効性が報告 されている. ${ }^{12}$

抗菌薬の予防的投与とは手術直前に開始される抗 菌薬の短期間投与のことであり，その目的は細菌す べてを殺菌するのではなく，細菌が宿主の感染防御 機能を越えて術後感染症に至るのを防ぐことにあ る. その効果を最大限に発揮させるためには，手術 中に惹起される污染菌に対して殺菌的であること, 抗菌薬の血中及び組織中濃度を治療域に保ち, 創が 閉じられたのちも数時間維持できることなどが重要 である。

心臟血管外科手術は，本来術野に細菌等の病原微 生物は少なく，無菌手術と考えられていることか ら, 術後感染予防抗菌薬は表皮常在細菌又は環境細 菌を対象として選択され，一般的にはペニシリン系 抗菌薬や第一世代のセフェム系抗菌薬が使用されて いる.

1998 年 5 月より心臓血管外科病棟で薬剂管理指 導業務を開始した際に，術後感染予防抗菌薬の投与 日数や, 術後感染症が発生した際に選択される抗菌 薬について疑問が生じた。欧米では術後感染予防抗 菌薬の適正使用に薬剤師が積極的に関与し，わが国 でも今以上に術後感染予防抗菌薬の適正使用に薬剤 師が関与していく必要があると報告されている. ${ }^{13)}$
そこでレトロスペクティブに抗菌薬の使用状況を調 査し，文献等により妥当性の評価を行い，その結果 について診療科と協議を行った。 それを受け，セフ アゾリン（CEZ）の投与方法が変更されたので報 告する.

\section{CEZ の使用状況と術後感染症の危険因子}

4-1. はじめに＼cjkstart冠動脈バイパス術は無菌手術 と考えられているものの，その多くは胸骨正中切開 が行われる，縦隔の血行が小さいことや，人工心肺 装置使用による体内への病原微生物進入の確率の増 加が原因となり，術後感染症に罹患し易い状況にあ る. $\left.{ }^{14}, 15\right)$

薬剤管理指導業務を通じて, 術後感染症を引き起 こす要因には患者側の要因と，手術による要因とが 存在していると考え, 術後感染予防抗菌薬として使 用されている CEZ の使用状況を調査し，検討を試 みた。 その結果に基づき，術後感染予防目的で使用 される CEZ 適正使用への薬学的支援の方向性を探 つた.

なお従来，冠動脈バイパス術は人工心肺装置を使 用し，心停止下で行われていたが (Coronary Artery Bypass Grafting; On-pump CABG), 近年器具 の発達に伴い，人工心肺装置を使用せず，心拍動下 で行われている。これを従来の冠動脈バイパス術と 区別し，Off-pump CABG（OPCAB）と呼ばれ， OPCAB を対象に検討を試みた。

4-2. 対象 当院心臓血管外科では術後感染予 防抗菌薬として CEZの単独投与を原則としてお り，手術室にて麻酔導入前に $1 \mathrm{~g}$ 点滴静注されてい る。術後の CEZ の投与量は 1 回 $1 \mathrm{~g}, 1$ 日 2 回とさ れてはいるものの，投与期間については担当医の判 断にて行われていた。対象は初回 OPCAB を受け た患者としたが，透析を受けている患者については 静注時での血中 CEZ 濃度の推移の相違や血液透析 による半減期の短縮により, 通常と CEZ の投与量 が異なっていることから除外した。なお，対象期間 は 2000 年 4 月より 2001 年 12 月とした.

4-3. 方法 CEZ の投与日数及び CEZ を他の 抗菌薬に変更する経過日数は担当医により異なって いた. 他の抗菌薬に変更される術後の経過日数は 57 日ほどであり，またそれ以上の症例も存在した. 白血球数（WBC）及び C 反応性タンパク（CRP） の高値の持続又は再上昇，発熱や創部の発赤の程度 
により変更する基準は様々であるが，術後 5 日以内 にCEZ を中止にした症例や他の抗菌薬に変更する 症例はみられなかった。

また，CEZ を変更する場合，その基準が様々で あり，血液培養など施行されていない症例も存在し た。こうした理由により感染のフォーカスが不明な 点があるため, 手術後の CEZ 変更の有無つまり, CEZ のみで術後感染症を予防できた症例（CEZ 単 独群）と，炎症所見を示す検査值異常や発熱等によ り CEZ を他の抗菌薬に変更した症例 (CEZ 変更群) とに分けて，両群の間で下記の項目について比較検 討した。なお，CEZ の投与中止後， CEZ の再投与 は行われていなかった。診療録の調査はレトロスペ クティブに行った.

検討項目

\begin{tabular}{|c|c|}
\hline $\begin{array}{l}\text { 患 } \\
\text { 者 } \\
\text { 側 } \\
\text { の } \\
\text { 要 } \\
\text { 因 }\end{array}$ & 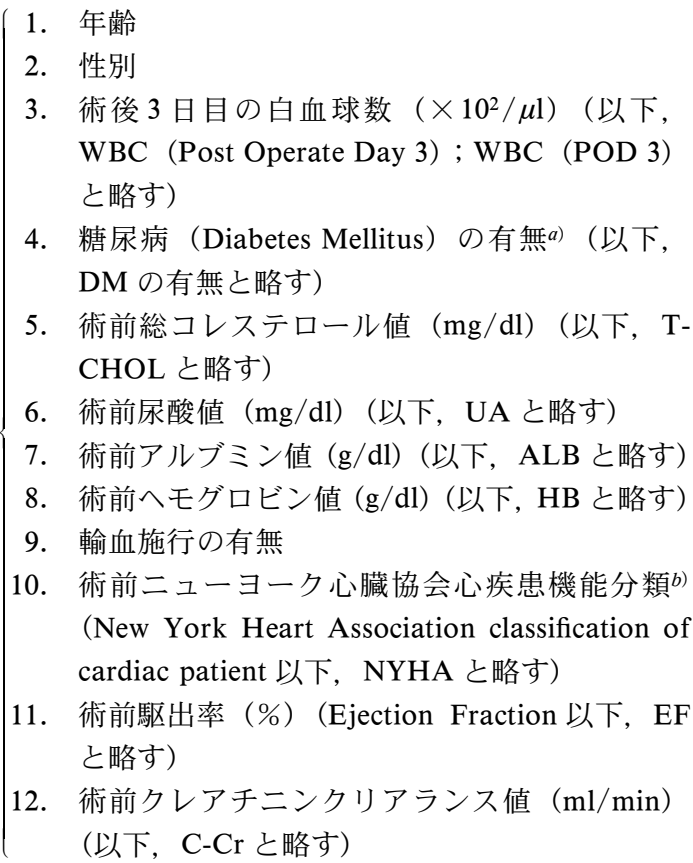 \\
\hline $\begin{array}{l}\text { 手要 } \\
\text { に } \\
\text { よ } \\
\text { る }\end{array}$ & $\begin{cases}13 . & \text { 手術時間 (h) } \\
\text { 14. } & \text { 内胸動脈の使用の相違c) } \\
15 . & \text { ドレーン挿入時間 }(\mathrm{h}) \\
16 . & \text { 待機手術・緊急手術の相違 }\end{cases}$ \\
\hline
\end{tabular}

a) 内服又はインスリン投与の有無による比較検討， $b$ ）Ｉ又はII と III 又は IV との比較検討， $c$ ) 両側内胸動脈の使用と片側内胸動脈の使 用又は未使用との比較検討.

4-4. 統計 性別, DM の有無, 輸血施行の有 無，術前 NYHA，内胸動脈の使用の相違及び待 機・緊急手術の相違の検定については $\chi^{2}$ 検定を, その他の項目については Mann-Whitney の $U$ 検定 を用い，危険率 $5 \%$ 及び $1 \%$ 以下の場合をもって有
意な差と評価した。Mann-Whitney の $U$ 検定での 結果はすべて平均值 \pm SD で示した。

4-5. 結果 対象患者数, 解析患者数, 除外患 者数はそれぞれ 427 名， 398 名，29名であった.

各手術における各検討項目の解析結果は Table 2 に示す．患者側の要因として，WBC（POD3）で有 意な差が認められ，CEZ 単独群の WBC（POD 3) の平均值が $89.1 \times 10^{2} / \mu 1$ であるのに対し，CEZ 変 更群のそれは $103.2 \times 102 / \mu 1$ であった，手術による 要因として，手術時間で有意な差が認められ， CEZ 単独群での平均手術時間が 4.9 時間であるの に対し，CEZ 変更群のそれは 5.6 時間であった.

また, CEZ 変更群での術後感染治療抗菌薬の内 訳を Table 3 に示す．カルバペネム系抗菌薬を使用 した症例が多く，カルバペネム系抗菌薬単独又は他 の抗菌薬との併用を合わせると， $85.3 \% （=64$ 症 例/75 症例）となっていた。ささらにそれらの抗菌 薬を変更する症例も 7 例存在した。

4-6. 考察＼cjkstart患者側の要因として，CEZ を変更 する症例が WBC（POD 3) の值と関連性があるこ とが明らかとなった。消化器外科領域での術後感染 予防抗菌薬の中止又は変更の目安の 1 つとして, WBC（POD 3）の值が $120 \times 10^{2} / \mu$ l であるとしてい るが，心臟血管外科領域では同様な報告は夕られ ず，この領域についても WBC（POD 3）の值の重 要性が示唆された。そして, WBC (POD 3) の值 として $100 \times 10^{2} / \mu 1$ がその值と考えられる.

一般的には抗菌薬を投与することにより $1 / 10^{6-7}$ の確率で耐性菌が出現し，術後感染症が発症した際 の原因菌の $70 \%$ 程度が術前より投与した感染予防 抗菌薬に耐性のある菌であること, ${ }^{16)}$ また使用され るべき次の感染治療薬は感染予防薬に対する耐性菌 を目標に選択する必要がある17)とされている．した がって，術後 5-7 日で行われていた CEZ の変更を より早い段階，例えば術後 3 日目の WBC の值を参 考にし，他の抗菌薬へ変更すべきか否か，検討の必 要があると考えられた。

手術による要因として，手術時間が 5 時間を超え ると，CEZ を変更する確率が高くなり，5時間を 超える手術の場合，CEZ 追加投与の必要性がある ことが判明した。皮膚切開が加えられた時点では有 効血中濃度または組織内濃度が保たれていたとして も，手術時間が延長した場合，手術終了時点まで有 
Table 2. Analysis Results (On-pump CABG, OPCAB)

\begin{tabular}{|c|c|c|c|c|c|c|c|}
\hline & \multicolumn{3}{|c|}{ On-pump CABG } & \multicolumn{3}{|c|}{$\begin{array}{c}\text { OPCAB } \\
(2000.4-2001.12) 398 \text { 症例 }\end{array}$} \\
\hline & & CEZ 単独群 & CEZ 変更群 & $p$ 值 & CEZ 単独群 & CEZ 変更群 & $p$ 值 \\
\hline \multirow{2}{*}{\multicolumn{2}{|c|}{$\begin{array}{l}\text { 症例数（例） } \\
\text { 全症例数に対する割合 (\%) }\end{array}$}} & 133 & 35 & & 323 & 75 & \\
\hline & & 79.2 & 20.8 & & 81.2 & 18.8 & \\
\hline \multirow{16}{*}{$\begin{array}{l}\text { 患 } \\
\text { 者 } \\
\text { 側 } \\
\text { 要 } \\
\text { 要 }\end{array}$} & (年齢（歳） & $65.6 \pm 8.3$ & $67.7 \pm 7.5$ & 0.0893 & $67.5 \pm 9.1$ & $69.0 \pm 8.5$ & 0.1488 \\
\hline & 14 미 $1 a)$ & 男性 94 & 男性 20 & 01272 & 男性 215 & 男性 49 & 0.83 \\
\hline & 性斺" & 女性 39 & 女性 15 & 0.1212 & 女性 108 & 女性 26 & 0.8391 \\
\hline & $\begin{array}{c}\text { WBC }(\text { POD 3) } \\
\left(\times 10^{2} / \mu \mathrm{l}\right)\end{array}$ & $105.8 \pm 23.7$ & $135.7 \pm 47.9$ & $\leq 0.0001$ & $89.1 \pm 24.7$ & $103.2 \pm 36.5$ & $\underline{0.0016}$ \\
\hline & \multirow{2}{*}{$\mathrm{DM}$ の有無 $a)$} & $(+) \quad 24$ & $(+) \quad 12$ & \multirow{2}{*}{$\underline{0.0372}$} & $(+) \quad 87$ & $(+)$ & \multirow{2}{*}{$\underline{0.0037}$} \\
\hline & & $(-) 109$ & $(-) \quad 23$ & & $(-) 236$ & $(-) \quad 42$ & \\
\hline & 術前 T-CHOL (mg/dl) & $197.2 \pm 32.8$ & $195.6 \pm 26.2$ & 0.9533 & $191.6 \pm 32.7$ & $192.8 \pm 33.3$ & 0.8063 \\
\hline & 術前 UA（mg/dl） & $5.7 \pm 1.4$ & $5.8 \pm 2.0$ & 0.8712 & $5.8 \pm 1.6$ & $5.6 \pm 1.9$ & 0.4188 \\
\hline & 術前 ALB（g/dl） & $4.4 \pm 0.4$ & $4.3 \pm 0.3$ & $\underline{0.0093}$ & $4.3 \pm 0.4$ & $4.2 \pm 0.4$ & 0.1306 \\
\hline & 術前 HB（g/dl） & $13.1 \pm 1.6$ & $12.6 \pm 1.5$ & $\overline{0.0519}$ & $13.0 \pm 1.7$ & $12.9 \pm 1.8$ & 0.7741 \\
\hline & 軨血旅行 $($ 右毎 $a$ ) & $(+) \quad 42$ & $(+) \quad 24$ & \multirow{2}{*}{$\leq 0.0001$} & $(+) \quad 90$ & $(+) \quad 36$ & \multirow{2}{*}{$\underline{0.0007}$} \\
\hline & 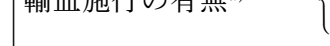 & $(-) \quad 91$ & $(-) \quad 11$ & & $(-) 233$ & $(-) \quad 39$ & \\
\hline & \multirow{2}{*}{ 術前 NYHA ${ }^{a}$} & (I or II) 99 & (I or II) 17 & \multirow{2}{*}{$\underline{0.0032}$} & (I or II) 270 & (I or II) $\quad 58$ & \multirow{2}{*}{0.1997} \\
\hline & & (III or IV) 34 & (III or IV) 18 & & (III or IV) 53 & (III or IV) 17 & \\
\hline & 術前 EF（\%） & $56.8 \pm 17.1$ & $58.2 \pm 12.9$ & 0.9284 & $57.8 \pm 14.2$ & $58.6 \pm 13.1$ & 0.6553 \\
\hline & 術前 C-Cr (ml/min) & $87.6 \pm 27.2$ & $84.7 \pm 33.7$ & 0.3163 & $79.4 \pm 27.5$ & $72.9 \pm 33.2$ & 0.0794 \\
\hline \multirow{5}{*}{$\begin{array}{l}\text { 手 } \\
\text { 術 } \\
\text { に } \\
\text { よ } \\
\text { る } \\
\text { 要 } \\
\text { 因 }\end{array}$} & (手術時間（h） & $4.5 \pm 1.0$ & $5.2 \pm 1.3$ & $\underline{\underline{0.0062}}$ & $4.9 \pm 1.3$ & $5.6 \pm 1.3$ & $\leq 0.0001$ \\
\hline & 内胸動脈使用の相違 ${ }^{a)}$ & $\begin{array}{c}\text { (両側) } 41 \\
\text { (片側 or 未使用) } 92\end{array}$ & $\begin{array}{c}\text { (両側） } 11 \\
\text { (片側 or 未使用) } 24\end{array}$ & 0.9454 & $\begin{array}{c}\text { (両側) } 257 \\
\text { (片側 or 未使用) } 66\end{array}$ & $\begin{array}{c}\text { (両側) } 60 \\
(\text { 片側 or 未使用) } 15\end{array}$ & 0.9331 \\
\hline & \multirow{3}{*}{ 待機手術・緊急手術の } & $46.6 \pm 21.4$ & $55.6 \pm 29.2$ & 0.1110 & $46.7 \pm 19.4$ & $59.8 \pm 30.8$ & 0.0041 \\
\hline & & （待機）109 & (待機) 24 & \multirow{2}{*}{0.0828} & (待機) 284 & (待機) 60 & \multirow{2}{*}{0.0710} \\
\hline & & （緊急） 24 & （緊急） 11 & & （緊急） 39 & （緊急） & \\
\hline
\end{tabular}

a) Number of patients. group).

$: p<0.05$ (CEZ-non-replaced group vs. CEZ-replaced group), $: p<0.01$ (CEZ-non-replaced group vs. CEZ-replaced

Table 3. Antimicrobial Agents for Infection in the Group in which CEZ was Switched

\begin{tabular}{|c|c|c|c|c|c|}
\hline & $\begin{array}{l}\text { CEZから変更 } \\
\text { された抗囷薬 }\end{array}$ & 症例数 & $\begin{array}{l}\mathrm{CEZ} \text { から他の抗 } \\
\text { 菌薬への変更日 }\end{array}$ & \multicolumn{2}{|c|}{ 変更抗菌薬の投与日数 } \\
\hline \multirow{10}{*}{ OPCAB } & $\mathrm{IPM} / \mathrm{CS}$ & 30 & 7.8 & & 6.3 \\
\hline & $\mathrm{PAPM} / \mathrm{BP}$ & 22 & 7.6 & & 6.1 \\
\hline & CTM & 5 & 9.0 & & 7.0 \\
\hline & $\mathrm{SBT} / \mathrm{CPZ}$ & 3 & 6.0 & & 3.3 \\
\hline & PIPC & 2 & 7.0 & & 6.0 \\
\hline & $\begin{array}{l}\mathrm{CEZ}+\mathrm{IPM} / \mathrm{CS} \\
(\mathrm{IPM} / \mathrm{CS} \text { 併用 })\end{array}$ & 6 & 7.3 & \multicolumn{2}{|c|}{$\begin{array}{l}\text { CEZ : 手術後 } 15 \text { 日間 } \\
\text { IPM/CS : } 10.2\end{array}$} \\
\hline & $\begin{array}{l}\mathrm{CEZ}+\mathrm{PAPM} / \mathrm{BP} \\
(\mathrm{PAPM} / \mathrm{BP} \text { 併用 })\end{array}$ & 1 & 7.0 & \multicolumn{2}{|c|}{$\begin{array}{l}\text { CEZ : 手術後 } 12 \text { 日間 } \\
\text { PAPM/BP : } 5.0\end{array}$} \\
\hline & $\mathrm{CTM}+\mathrm{TOB}$ & 1 & 11 & CTM : 5.0 & TOB $: 5.0$ \\
\hline & $\mathrm{CTM}+\mathrm{IPM} / \mathrm{CS}$ & 2 & 6.0 & \multicolumn{2}{|c|}{ CTM $: 7.5 \quad$ IPM/CS $: 12.5$} \\
\hline & $\mathrm{IPM} / \mathrm{CS}+\mathrm{VCM}$ & 3 & 6.0 & \multicolumn{2}{|c|}{ IPM/CS : 6.6 VCM $: 6.6$} \\
\hline
\end{tabular}

a) Mean interval from surgery. IPM/CS: Imipenem/Cilastatin, PAPM/BP: Panipenem/Betamipron, CTM: Cefotiam, SBT/CPZ: Sulbactam/ Cefoperazone, PIPC: Piperacillin, TOB: Tobramycin, VCM: Vancomycin. 
効血中濃度を保つためには CEZ の追加投与が必要 となる，その延長時間としては，オーストラリア治 療ガイドライン委員会の抗生物質治療ガイドライン によれば，初回投与からその抗菌薬の通常投与間隔 の $1 / 2$ を超えた場合と報告している。 CEZ の投与 間隔である 8-12 時間の 1/2つまり 4-6 時間を超え た手術では CEZ の追加投与が必要となり, 今回の 検討結果と合致する.

感染治療抗菌薬に注目した場合，両手術とも CEZ の変更は術後 1 週間程度で行われ，その $80 \%$ 以上をカルバペネム系抗菌薬が占めていた，術後の WBC やCRP などの検査值の推移，発熱や創部の 状態など感染治療抗菌薬を使用する基準は様々であ る.今回の検討では, 変更される感染治療抗菌薬は 感染予防抗菌薬に対する耐性菌を目標に選択する必 要がある17)ことや，またその耐性菌が 1/106-7 の確 率で出現し，原因菌の $70 \%$ 程度が術前から投与さ れた感染予防抗菌薬に耐性があること, ${ }^{16)}$ そして耐 性緑膿菌の問題点 ${ }^{18)}$ 等により Empiric therapy で使 用する抗菌薬について再考する必要があった.

まとめとして，CEZ 適正使用のための要因が明 らかとなり，術後感染の患者側の危険因子として術 後 3 日目の白血球数，DM 及び輸血施行が，手術に よる危険因子として手術時間が考えられた。また， 術後 3 日目の白血球数が $100 \times 10^{2} / \mu 1$ 以上の場合, CEZ を変更する必要性が認められ，手術時間が両 手術とも 5 時間を超えた場合，CEZ の術中追加投 与を実施する必要性があると考えられた。

\section{CEZ の適正使用指針の作成及びその変化}

5-1. はじめに 診療科に問題提起する際, OPCAB の夕でなく，弁膜症に対する手術（以下， Valve operation と略す）も対象に加え, CEZ の使 用状況を調查した。 さらにその検討結果について診 療科と協議を行い，CEZ の投与方法の変更 (以下, プロトコール変更と略す）を行い，プロトコール変 更後の CEZ 及び治療抗菌薬の使用状況の変化につ いて調査した.

5-2. 対象対象症例は初回 OPCAB 及び初回 Valve operation を受けた患者とした。プロトコー ル変更前の対象期間を 2001 年 1 月より 2002 年 12 月とし，プロトコール変更後の対象期間を 2003 年 2 月より 2003 年 11 月とした。 なお，プロトコール 変更前後の相違点は以下に示す。
いずれの期間も透析症例を除外し，また感染性心内 膜炎で術前から抗菌薬投与を受けている症例につい ても除外した.

プロトコール変更前後の相違点

プロトコール変更前（2002 年 12 月まで）

- 麻酔導入前に CEZ $1 \mathrm{~g}$ 静注し，手術時間が延 長した際の術中投与は行わず

- CEZ の術後投与期間は各担当医にて判断 プロトコール変更後（2003 年 2 月より）

- 麻酔導入前に CEZ1g 静注し，手術時間が 4 時間を超えた場合, CEZ $1 \mathrm{~g}$ を術中追加投与

- CEZ の術後投与期間は術後 2 日間

5-3. 方法 CEZのみで術後感染症を予防でき た症例（CEZ 単独群）と，炎症所見を示す検査值 異常や発熱等により CEZ を他の抗菌薬に変更した 症例（CEZ 変更群）とに分け，両群間で比較検討 した，検討項目は前述と同様とした.

なお，プロトコール変更後は CEZ の術後投与期 間が全症例術後 2 日間と定められたため, CEZ 単 独群を CEZ 投与が術後 2 日間のみで他の抗菌薬に 変更しなかった症例， $\mathrm{CEZ}$ 変更群を $\mathrm{CEZ}$ 投与後, 他の抗菌薬へ変更した症例とし，同様に比較検討し た.プロトコール変更前後とも術後感染予防を目的 とした CEZ の投与中止後は，その後の術後経過に おいて再度，感染治療を目的とした CEZ の投与は 行われていなかった。診療録の調査はレトロスペク ティブに行った.

5-4. 統計 性別, DM の有無, 輸血施行の有 無，術前 NYHA，内胸動脈の使用の相違及び待 機・緊急手術の相違の項目については $\chi^{2}$ 検定を, その他の項目については Mann-Whitney の $U$ 検定 を用い，Mann-Whitneyの $U$ 検定での結果はすべ て平均值 $\pm \mathrm{SD}$ で示した。 また，これらの検定にて $p$ 值が 0.01 以下を示した検討項目について多変量 ロジスティック回帰分析を用い，危険率 $5 \%$ 以下の 場合をもって有意差と評価した。

\section{5-5. 結果}

5-5-1. プロトコール変更前 対象患者数, 解 析患者数，除外患者数は OPCAB ではそれぞれ 544 名, 524 名, 20 名であり, Valve operation ではそれ ぞれ 300 名，262 名，38 名であった。各検討項目に 対する解析結果を Table 4 に示す.

患者側の要因として，両手術とも，WBC（POD3） 
Table 4. Analysis Results (Before the dosing guidelines for CEZ changes)

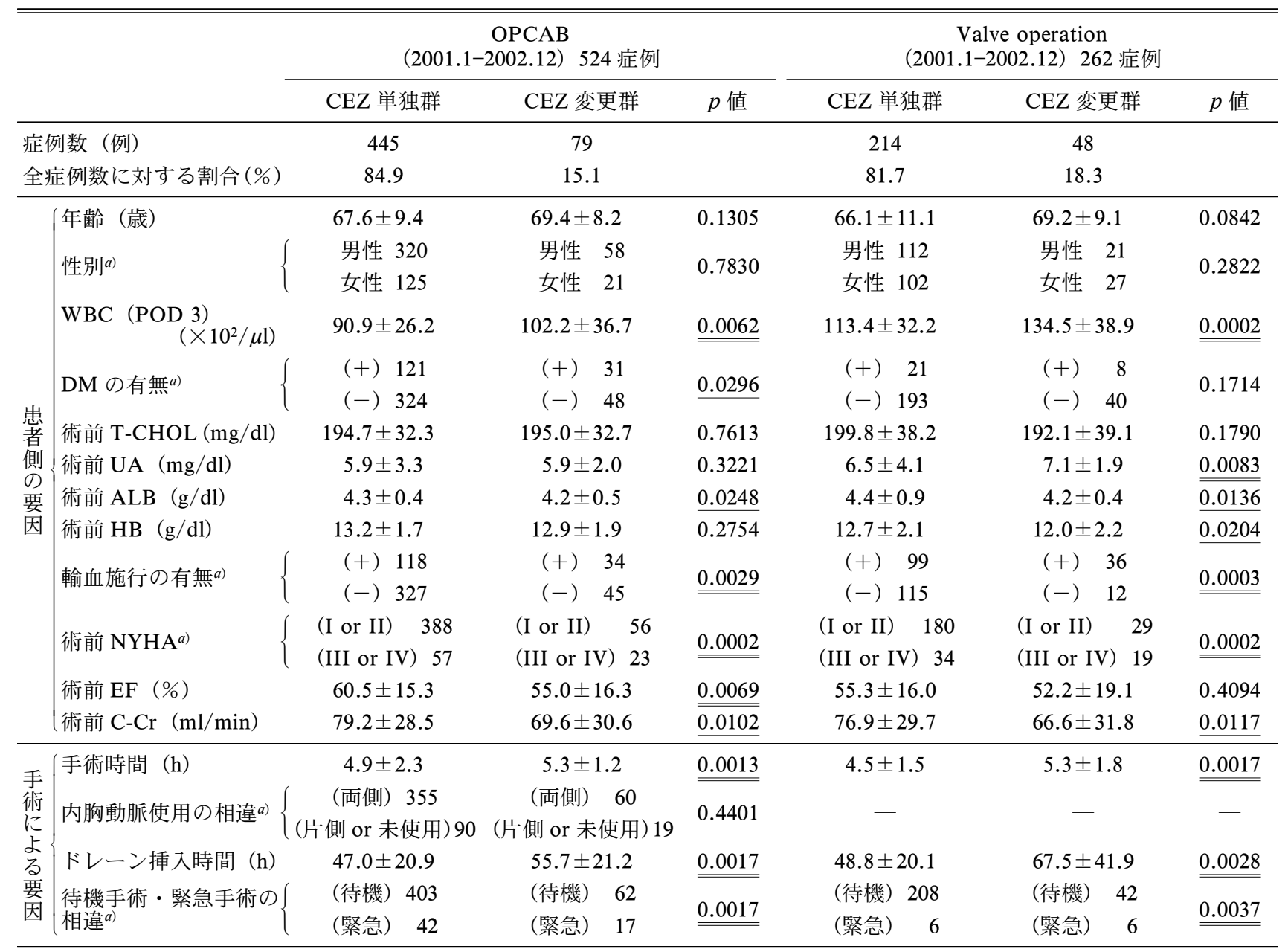

a) Number of patients. $: p<0.05$ (CEZ-non-replaced group $v s$. CEZ-replaced group), $: p<0.01$ (CEZ-non-replaced group $v s$. CEZ-replaced group).

で有意差が認められた。 OPCAB での CEZ 単独群 及び CEZ 変更群の $\mathrm{WBC}(\mathrm{POD} 3)$ の平均值はそれ ぞれ $90.9 \times 10^{2} / \mu 1,102.2 \times 10^{2} / \mu 1$ であり, Valve operation でのそれらはそれぞれ $113.4 \times 10^{2} / \mu 1$, $134.5 \times 10^{2} / \mu 1$ であった.

手術による要因として，手術時間が両手術とも有 意差が認められ， OPCAB での CEZ 単独群及び $\mathrm{CEZ}$ 変更群の平均手術時間はそれぞれ 4.9 時間,

5.3 時間であるのに対し，Valve operation でのそれ はそれぞれ 4.5 時間， 5.3 時間であった。

5-5-2. プロトコール変更後 対象患者数, 解 析患者数，除外患者数は OPCAB ではそれぞれ 225 名, 212 名, 13 名であり, Valve operation ではそ れぞれ 165 名，154 名，11名であり，各検討項目に 対する解析結果を Table 5 に示す.

患者側の要因として，両手術ともWBC（POD3）
で有意差が認められた。 OPCAB での CEZ 単独群 及び CEZ 変更群の $\mathrm{WBC}$ (POD3) の平均值はそれ ぞれ $88.9 \times 10^{2} / \mu \mathrm{l}, 131.8 \times 10^{2} / \mu \mathrm{l}$ であり，Valve operation でのそれはそれぞれ $108.8 \times 10^{2} / \mu 1,123.4$ $\times 10^{2} / \mu \mathrm{l}$ であった.

また，プロトコール変更前は手術時間において両 手術とも有意差が認められたが，プロトコール変更 後は両手術で有意差は認められなかった。OPCAB での $\mathrm{CEZ}$ 単独群及び CEZ 変更群の平均手術時間 はともに 5.0 時間であり, Valve operation でのそ れはそれぞれ 4.4 時間, 4.8 時間という結果であっ た.

5-5-3. プロトコール変更前後の相違点について

1） $\mathrm{CEZ}$ 変更率について プロトコール変更前 後での $\mathrm{CEZ}$ 変更率について調査した. プロトコー ル変更前は OPCAB で $15.1 \%$ (=79 症例/524 症例 $)$, 
Table 5. Analysis Results (After the dosing guidelines for CEZ changes)

\begin{tabular}{|c|c|c|c|c|c|c|c|}
\hline & \multicolumn{3}{|c|}{ OPCAB } & \multicolumn{3}{|c|}{ Valve operation } \\
\hline & & \multicolumn{3}{|c|}{ (2003.2-2003.11) 212 症例 } & \multicolumn{3}{|c|}{ (2003.2-2003.11) 154 症例 } \\
\hline & & CEZ 単独群 & CEZ 変更群 & $p$ 值 & CEZ 単独群 & CEZ 変更群 & $p$ 值 \\
\hline \multirow{2}{*}{\multicolumn{2}{|c|}{$\begin{array}{l}\text { 症例数（例） } \\
\text { 全症例数に対する割合（\%) }\end{array}$}} & 193 & 19 & & 136 & 18 & \\
\hline & & 91.0 & 9.0 & & 88.3 & 11.7 & \\
\hline \multirow{16}{*}{$\begin{array}{l}\text { 患 } \\
\text { 者 } \\
\text { 側 } \\
\text { の } \\
\text { 要 } \\
\text { 因 }\end{array}$} & \multirow{3}{*}{$\begin{array}{l}\text { 年齢（歳） } \\
\text { 性別 } a)\end{array}$} & $67.1 \pm 9.3$ & $70.9 \pm 8.2$ & 0.1278 & $66.0 \pm 11.6$ & $68.0 \pm 10.2$ & 0.7400 \\
\hline & & 男性 150 & 男性 14 & 06004 & 男性 80 & 男性 12 & 05237 \\
\hline & & 女性 43 & 女性 5 & 0.0884 & 女性 56 & 女性 & 0.5231 \\
\hline & $\begin{array}{c}\text { WBC }(\text { POD 3) } \\
\left(\times 10^{2} / \mu \mathrm{l}\right)\end{array}$ & $88.9 \pm 22.6$ & $131.8 \pm 42.0$ & $\leq 0.0001$ & $108.8 \pm 26.3$ & $123.4 \pm 25.9$ & $\underline{0.0158}$ \\
\hline & \multirow{2}{*}{ DM の有無 $a)$} & $(+) \quad 65$ & $(+) \quad 10$ & 00002 & $(+) \quad 18$ & $(+)$ & \multirow{2}{*}{0.6901} \\
\hline & & $(-) 128$ & $(-) \quad 9$ & 0.0992 & $(-) 118$ & $(-) \quad 15$ & \\
\hline & 術前 T-CHOL (mg/dl) & $193.4 \pm 33.4$ & $178.3 \pm 38.4$ & 0.0723 & $200.3 \pm 36.3$ & $193.1 \pm 40.6$ & 0.3773 \\
\hline & 術前 UA（mg/dl） & $6.1 \pm 1.7$ & $5.5 \pm 1.8$ & 0.1244 & $6.8 \pm 2.0$ & $6.7 \pm 1.7$ & 0.8971 \\
\hline & 術前 ALB（g/dl） & $4.3 \pm 0.3$ & $3.9 \pm 0.6$ & 0.0014 & $4.4 \pm 0.4$ & $4.0 \pm 0.4$ & 0.0011 \\
\hline & 術前 HB（g/dl） & $13.1 \pm 1.6$ & $12.6 \pm 1.7$ & 0.2846 & $12.9 \pm 1.6$ & $13.0 \pm 2.1$ & $\overline{0.6691}$ \\
\hline & 㢵血旅行 $の$ 右舞 $a$ ) & $(+) \quad 54$ & $(+) \quad 8$ & 01965 & $(+) \quad 58$ & $(+) \quad 10$ & 03000 \\
\hline & 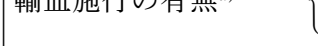 & $(-) 139$ & $(-) 11$ & 0.1903 & $(-) \quad 78$ & $(-)$ & 0.5000 \\
\hline & 術前 NYHA ${ }^{a}$ ) & (I or II) 172 & (I or II) 12 & 00014 & (I or II) 119 & (I or II) & 03000 \\
\hline & & (III or IV) 21 & (III or IV) 7 & & (III or IV) 17 & (III or IV) & 0.3000 \\
\hline & 術前 EF（\%） & $58.7 \pm 13.8$ & $55.1 \pm 13.1$ & 0.2342 & $56.0 \pm 17.6$ & $44.0 \pm 17.6$ & $\underline{0.0081}$ \\
\hline & 術前 C-Cr (ml/min) & $78.6 \pm 28.8$ & $69.7 \pm 28.2$ & 0.2404 & $74.7 \pm 27.0$ & $62.9 \pm 28.4$ & $\overline{0.1147}$ \\
\hline \multirow{5}{*}{$\begin{array}{l}\text { 手 } \\
\text { 術 } \\
\text { に } \\
\text { よ } \\
\text { る } \\
\text { 要 } \\
\text { 因 }\end{array}$} & \multirow{5}{*}{$\begin{array}{l}\text { 手術時間 (h) } \\
\text { 内胸動脈使用の相違 } a) \\
\text { ドレーン挿入時間 }(\mathrm{h}) \\
\text { 待機手術・緊急手術の } \\
\text { 相違 } a)\end{array}$} & $5.0 \pm 1.3$ & $5.0 \pm 1.3$ & 0.6353 & $4.4 \pm 1.7$ & $4.8 \pm 2.0$ & 0.4021 \\
\hline & & $\begin{array}{c}\text { (両側) } 146 \\
(\text { 片側 or 未使用) } 47\end{array}$ & $\begin{array}{c}\text { (両側） } 16 \\
\text { (片側 or 未使用) } 3\end{array}$ & 0.4015 & - & - & - \\
\hline & & $43.8 \pm 17.1$ & $62.7 \pm 35.8$ & $\underline{0.0073}$ & $46.8 \pm 18.4$ & $68.0 \pm 49.9$ & $\underline{0.0256}$ \\
\hline & & (待機) 171 & (待機) 11 & 00002 & (待機) 132 & (待機) 15 & 00086 \\
\hline & & （緊急） 22 & （緊急） & 0.0002 & （緊急） 4 & （緊急） & 0.0086 \\
\hline
\end{tabular}

a) Number of patients. $: p<0.05$ (CEZ-non-replaced group vs. CEZ-replaced group), $: p<0.01$ (CEZ-non-replaced group vs. CEZ-replaced group).

Valve operation で $18.3 \% （=48$ 症例 $/ 262$ 症例）で あったものの，プロトコール変更後は OPCAB で $9.0 \%(=19$ 症例 $/ 212$ 症例 $)$, Valve operation で $11.7 \%(=18$ 症例 $/ 154$ 症例）であり, CEZ 変更率 は両手術とも減少していた。また，手術時間を 4.0 時間以下，4.1 時間以上 5.0 時間以下，5.1 時間以 上 6.0 時間以下， 6.1 時間以上とし，手術時間別で の CEZ 変更率を調査した（Fig. 4, Fig. 5). 両手術 とも, プロトコール変更後の手術時間が延長した際 の $\mathrm{CEZ}$ 変更率は減少していた.

2) $\mathrm{CEZ}$ 変更群での感染治療抗菌薬使用の変化 について CEZ 変更群での術後感染治療抗菌薬の 内訳を Table 6 に示す。プロトコール変更前は $\mathrm{CEZ}$ 変更後の術後感染治療抗菌薬として, カルバ ペネム系抗菌薬を使用した症例が多く, カルバペネ 厶系抗菌薬単独及び他の抗菌薬との併用を合わせる
と, OPCAB で $81.0 \%(=64$ 症例 $/ 79$ 症例 $)$, Valve operation で $81.3 \%(=39$ 症例/48 症例）であつた.

また，CEZから他の抗菌薬へ変更された術後経過 日数は OPCAB で 6 日から 8 日, Valve operation で 5 日から 7 日であった。

プロトコール変更後は CEZ の投与方法の変更に 伴い, 第 2 選択薬としてのカルバペネム系抗菌薬の 問題について診療科へ問題提起した結果, 第 2 選択 薬をスルバクタムセセフォペラゾン（SBT/CPZ） を中心として使用することが診療科の方針となっ た. そのため, プロトコール変更後の術後感染治療 抗菌薬は SBT/CPZ が OPCAB で 84.2\%（=16 症 例 $/ 19$ 症例 $)$, Valve operation で $66.7 \% \quad(=12$ 症例 /18 症例）を占めるようになつた.

5-6. 考察プロトコール変更前において, 両 手術とも $\mathrm{CEZ}$ を変更する症例が WBC (POD 3) 


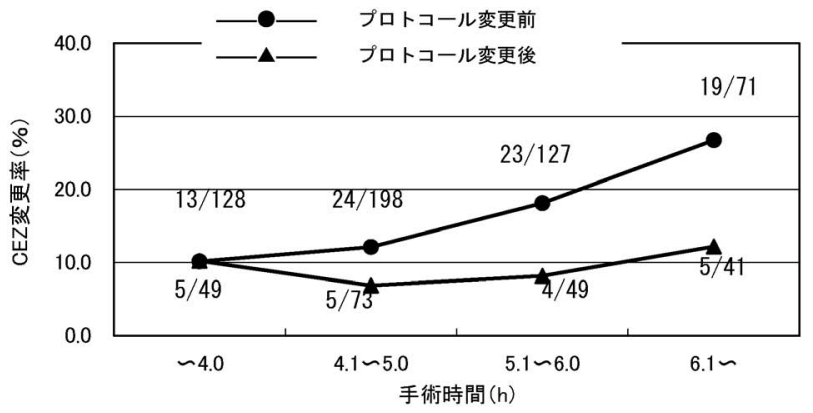

Fig. 4. Rate at which CEZ was Switched with Respect to the Duration of Surgery (OPCAB)

The values in the graph represent: number of patients in whom CEZ was switched/number of patients with respect to the duration of surgery.

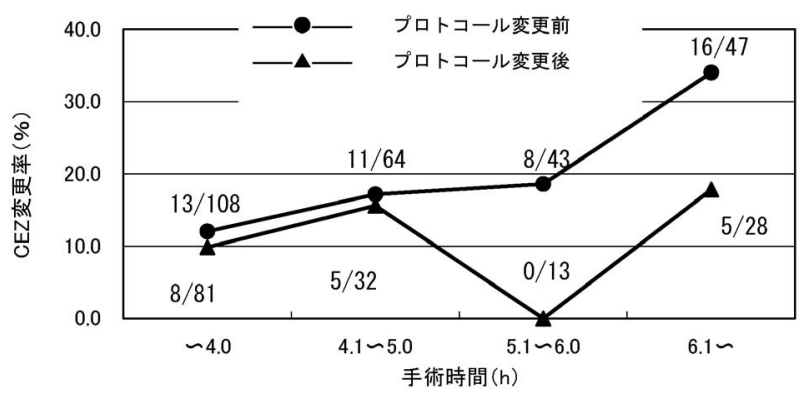

Fig. 5. Rate at which CEZ was Switched with Respect to the Duration of Surgery (Valve Operation)

The values in the graph represent: number of patients in whom CEZ was switched/number of patients with respect to the duration of surgery.
の值と関連することが予測され，OPCAB，Valve operation を対象とした調査の結果, 消化器外科領 域と同様に抗菌薬の中止又は変更の目安の 1 つとし て，WBC（POD 3）の值が重要であることが判明 した。手術時間について，5 時間を超える手術の場 合，CEZ を変更する割合が高くなると考えられ る。これは手術時間が延長した際の術中 CEZ 追加 投与の未実施によるものと考えられ，手術終了時点 まで有効血中濃度を保つためには CEZ の追加投与 が必要となるであろう.

CEZ を変更する症例と WBC (POD 3) の值及び 手術時間との関連について診療科へ報告した結果, プロトコール変更が行われた。つまり，1）WBC (POD 3) の結果にて CEZ の術後投与日数を術後 2 日間のみとし, 術後 3 日目より術後感染予防目的で の CEZ を中止とすること，2）感染治療抗菌薬の 必要性の有無については WBC（POD 3）の值を判 断材料の 1 つとすること，3）手術時間での検討結 果によりプロトコール変更前は麻酔導入前の CEZ $1 \mathrm{~g}$ 静注のみであったが，プロトコール変更後は麻 酔導入前の CEZ $1 \mathrm{~g}$ 静注に加え，手術時間が 4 時間 を超えた際，術中 CEZ 追加投与を行うこととなつ た.

この結果， CEZ の術後投与期間が 2 日間へと短

Table 6. Antimicrobial Agents for Infection in the Group in which CEZ was Switched

\begin{tabular}{|c|c|c|c|c|c|c|c|}
\hline \multirow{2}{*}{\multicolumn{2}{|c|}{ 第 2 選択薬 }} & \multicolumn{3}{|c|}{ OPCAB } & \multicolumn{3}{|c|}{ Valve operation } \\
\hline & & 症例数 & $\begin{array}{l}\text { 第 } 2 \text { 選択薬へ変更さ } \\
\text { れた平均後経過日 }\end{array}$ & $\begin{array}{l}\text { 変更抗菌薬 } \\
\text { の投与日数 }\end{array}$ & 症例数 & $\begin{array}{l}\text { 第 } 2 \text { 選択薬へ変更さ } \\
\text { れた平㳦後経過日 }\end{array}$ & $\begin{array}{l}\text { 変更抗菌薬 } \\
\text { の投与日数 }\end{array}$ \\
\hline \multicolumn{2}{|c|}{ 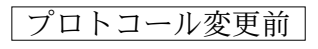 } & \multicolumn{3}{|c|}{ OPCAB（79 症例） } & \multicolumn{3}{|c|}{ Valve operation（48 症例） } \\
\hline \multirow{4}{*}{$\begin{array}{l}\text { カ系 } \\
\text { 抗 } \\
\text { バ囷 } \\
\text { ヘ薬 } \\
\text { ネ } \\
\text { ム }\end{array}$} & IPM/CS & 34 & 8.4 & 7.2 & 23 & 7.0 & 6.8 \\
\hline & $\begin{array}{l}\mathrm{IPM} / \mathrm{CS}+ \\
\text { 他の抗菌薬 }\end{array}$ & 9 & 6.6 & 8.6 & 4 & 6.0 & 8.8 \\
\hline & $\mathrm{PAPM} / \mathrm{BP}$ & 21 & 6.4 & 6.6 & 11 & 6.3 & 9.2 \\
\hline & $\begin{array}{l}\mathrm{PAPM} / \mathrm{BP}+ \\
\text { 他の抗菌薬 }\end{array}$ & 0 & - & - & 1 & 6.0 & 9.0 \\
\hline \multirow{2}{*}{\multicolumn{2}{|c|}{$\begin{array}{l}\text { 他のセフェム系抗菌薬 } \\
\text { 上記以外の抗菌薬 }\end{array}$}} & 8 & 7.5 & 6.5 & 4 & 5.5 & 5.0 \\
\hline & & 7 & 8.4 & 7.6 & 5 & 6.8 & 6.5 \\
\hline \multicolumn{2}{|c|}{ プロトコール変更後 } & \multicolumn{3}{|c|}{ OPCAB（19 症例） } & \multicolumn{3}{|c|}{ Valve operation（18 症例） } \\
\hline \multirow{4}{*}{\multicolumn{2}{|c|}{$\begin{array}{l}\mathrm{SBT} / \mathrm{CPZ} \\
\mathrm{SBT} / \mathrm{CPZ}+\text { 他の抗菌薬 } \\
\text { 他のセフェム系抗菌薬 } \\
\text { 上記以外の抗菌薬 }\end{array}$}} & 16 & 4.2 & 5.7 & 12 & 4.3 & 11.3 \\
\hline & & 1 & 3.0 & 15.0 & 1 & 3.0 & 5.0 \\
\hline & & 1 & 7.0 & 15.0 & 4 & 6.8 & 5.5 \\
\hline & & 1 & 5.0 & 4.0 & 1 & 3.0 & 9.0 \\
\hline
\end{tabular}

End of the administration of antimicrobial agents replacing CEZ: Date on which the administration of all antimicrobial agents was completed in the combination therapy ( 2 agents) group. IPM/CS: Imipenem/Cilastatin, PAPM/BP: Panipenem/Betamipron, SBT/CPZ: Sulbactam/Cefoperazone. 
縮されたにも係わらず（プロトコール変更前の CEZ の術後投与期間は OPCAB で平均 7.7 日, Valve operation で平均 8.7 日), CEZ を変更する症 例の割合は両手術とも減少した。 また, Fig. 4, Fig. 5 で示す通り，両手術でプロトコール変更後，手術が 延長した際の CEZ 変更率が低下していることか ら，手術時間が 4 時間を超えた際の術中 CEZ 追加 投与の有効性が明らかとなった。

プロトコール変更前の感染治療抗菌薬の 8 割以上 がカルバペネム系抗菌薬であり，その問題点をプロ トコールの見直しと同時に，診療科へ問題提起を行 つた．培養の結果が出るまでの Empiric therapy に ついては SBT/CPZ を中心に使用することが診療科 の方針となり，培養結果にて続行又は変更が行われ ている.

まとめとして，手術時間や術後投与期間を考慮し た CEZ の適正使用指針を作成し，その指針に基づ いた投与方法の変更の結果，手術時間が延長した際 の CEZ から他の抗菌薬への変更例が減少し, 術中 $\mathrm{CEZ}$ 追加投与の有効性が明らかとなった。また， プロトコール変更前, CEZ から変更されている感 染治療抗菌薬の大部分がカルバペネム系抗菌薬であ つたが，耐性緑膿菌の問題点を考慮し，現在，スル バクタム／セフォペラゾンの使用が行われて，不必 要なカルバペネム系抗菌薬の使用頻度を減少させる ことができた.

今回，術後感染予防目的に使用されている CEZ の使用状況について CEZ 変更の有無から患者側の 要因及び手術による要因に注目し，調査した。その 検討結果を診療科へ提示することにより術後感染予 防抗菌薬としての CEZ の適正使用及び，患者に対 しては不要な抗菌薬使用を回避できたと考える．薬 剂管理指導業務を遂行する中で，薬剤使用について の疑問点から今回の検討を進め, 診療科との協議に おいて 1 つの結果を導き出せたが，最近，叫ばれて いる薬剤管理指導業務の質の向上を遂行していくた めには患者との服薬指導を通して，患者の状態，検 査值の変動等を把握することにより，薬剤の使用方 法について検討を行うことが重要である．また，医 師との薬学的協議により薬剤の使用方法が変更され た場合，アウトカムを評価することがさらに重要で ある．大井らは薬剤管理指導業務における薬学的協 議の実践を報告し，薬剤管理指導業務を通じた質の
向上について薬剤管理指導業務のフローチャートを 示している19)が，こうした薬学的考察を行うこと で，医薬品適正使用に資する薬学的支援を推進でき ると考える。

\section{REFERENCES}

1) Nakashima H., Tsutsumi K., Hashiguchi M., Ebihara A., Jpn. J. Clin. Pharmacol. Ther., 20, 441-446 (1989).

2) Tsutsumi K., Nakashima H., Tateishi T., Imagawa M., Nakano S., J. Clin. Pharmacol., 33, 154-160 (1993).

3) Gotou N., Aoike M., Terasawa Y., Nakamura T., Masada M., Sugimoto I., TDM Kenkyu, 18 (1) , 55-60 (2001)

4) Channer K. S., Br. J. Clin. Pharmacol., 32, 267-273 (1991).

5) Ishikawa T., Teikyou Igaku Zasshi, 17, 123132 (1994)

6) Ohgitani S., Hunaki M., Hatsuda K., Katayama Y., Ito K., Tanaka K., Kodama J., Kushiro H., Eiseikensa, 33, 143-147 (1983) .

7) Cockcroft D. W., Gault M. H., Nephron, 16, 31-34 (1976).

8) Okada R. D., Hager W. D., Graves P. E., Mayersohn M., Perrier D. G., Marcus F. I., Circulation, 58, 1196-1203 (1978).

9) Verschraagen M., Koks C. H. W., Schellens J. H. M., Beijnen J. H., Pharmacol. Res., 40, 301-306 (1999).

10) Zatuchni J., Am. Heart J., 108, 412-413 (1984).

11) Guglielmo B. J., Hohn D. C., Koo P. J., Hunt T. K., Sweet R. L., Conte Jr. J. E. Jr., Arch. Surg., 118 (8), 943-955 (1983).

12) Classen D. C., Evans R. S., Pestotnik S. L., Horn S. D., Menlove R. L., Burke J. P., N. Engl. J. Med., 326, 281-286 (1992).

13) Yokoyama T., Hiyama E., Takesue Y., Gekkan Yakuzi, 45(6), 29-34 (2003).

14) Rebollo M. H., Bernal J. M., Llorca J., Rabasa J. M., Revuelta J. M., J. Thorac. Cardiovasc. Surg., 112 (4), 908-913 (1996) .

15) Murphy P. J., Connery C., Hicks Jr. G. L., Blumberg N., J. Thorac. Cardiovasc. Surg., 104 (4), 1092-1099 (1992).

16) Yokoyama T., Hiyama E., “Sousyou • Ensyou • Toutuukanri no Tebiki”, ed. by Ogawa 
M., Ishiyaku syuppan Co., Ltd., Tokyo, 1996, pp. 22-27.

17) Sumiyama Y., Yakkyoku, 52, 2176-2181 (2001)

18) Hirakata Y., "Taiseikinkansensyou no Riron to Zissen," ed. by Hiramatsu K., Medicine and Drug Journal Co., Ltd., Tokyo, 2002, pp. 252-259.

19) Ooi K., Katayama T., Fuzioka M., Jpn. J. Pharm. Health Care Sci., 29, 107-110 (2003). 